International Journal of Osteoarchaeology

Int. J. Osteoarchaeol. (2011)

Published online in Wiley Online Library

(wileyonlinelibrary.com) DOI: 10.1002/oa.1260

\title{
Syndactyly in Pigs: A Review of Previous Research and the Presentation of Eight Archaeological Specimens
}

\author{
R. MADGWICK, ${ }^{a *}$ V. FOREST ${ }^{\text {b }}$ AND F. BEGLANE ${ }^{\mathbf{c}}$ \\ a School of Applied Sciences, Bournemouth University, Poole, Dorset, UK \\ b Institut national de recherches archéologiques préventives (Montpellier), Laboratoire UMR5608 TRACES- \\ CRPPM (Toulouse), F-34000 Montpellier, France \\ c School of Science, Institute of Technology, Sligo, Ireland
}

\begin{abstract}
This paper reviews evidence for the rare condition of porcine syndactyly. It describes eight archaeological examples from Britain, Northern Ireland and France. Syndactyly refers to the partial or complete fusion of two or more adjacent phalanges on the medio-lateral border. The degree and character of fusion are variable, but phalanges frequently unite to create a single skeletal element. This condition has been identified by veterinarians, zoologists and naturalists in individuals and populations in a range of species, but in spite of substantial research on the condition in humans and to a lesser extent cattle, it remains relatively poorly understood in other mammals. Syndactyly is generally agreed to be primarily congenital in origin, although factors affecting its incidence remain far from fully understood. In light of the general paucity of discussion of specific conditions of animal palaeopathology, this paper presents an analysis of these newly discovered syndactyle pig specimens, offers a review of research with particular reference to pigs and discusses the etiology of the condition. Copyright (C) 2011 John Wiley \& Sons, Ltd.
\end{abstract}

Key words: palaeopathology; pigs; syndactyly

\section{Introduction}

In stark contrast to research in the field of human osteoarchaeology, the study of palaeopathology in zooarchaeology has, in relative terms, been neglected. All too often, anomalous bones and idiopathic lesions have been afforded only short notes or brief descriptions in faunal reports with little synthetic work being carried out on specific conditions, a trend in research that was noted over 30years ago (Siegel, 1976). Although the field of zoopalaeopathology is rapidly progressing and research papers are becoming more common (e.g. Miklíková and Thomas, 2008), zooarchaeology as a discipline would benefit from a greater number of holistic studies on specific conditions. As useful as texts such as Baker and Brothwell's (1980) seminal work on zoopalaeopathology are, further fine-grained research on particular pathologies is needed in order to gain a detailed understanding of

* Correspondence to: School of Applied Sciences, Bournemouth University,

Talbot Campus, Fern Barrow, Poole, Dorset, UK.

e-mail:rmadgwick@bournemouth.ac.uk the implications of these diseases at both an individual and population level. In light of these shortfalls, this paper presents a synthesis of research on porcine syndactyly, the partial or complete fusion of two or more phalanges in pigs.

Throughout this paper the term, 'syndactyly' is used as the noun for the disorder and 'syndactyle' is used as the adjective. The term syndactyly did not come into use until the first half of the 19th century, when it was used to describe the fusion of toes in passerines by the French naturalist Cuvier (1805) and was subsequently used by English naturalists such as Whewell (1840), Partington (1835) and Swainson (1836). Early use of the term tended to refer to the morphology of certain species rather than to the pathological or congenital abnormalities. The terminology used to describe the condition remains varied and includes syndactyly (Hurlin, 1920; Goodrich, 1935 and many more), syndactylism (Groves, 1913; Scott, 1933), zygodactyly (Stiles and Hawkins, 1946; Alvord, 1947), syndactylia (Fujimoto et al., 1958; Lauschke, 1988) and monodactyly (Ghetie and Dinu, 1957; Brothwell, 2008: 120). 


\section{Background}

The first known reference to syndactyly in pigs (although not the use of the term) was by Aristotle, around 350 BC (trans. Peck, 1965: 89), who described swine as 'dualizers' in that some were cloven hoofed and others, particularly in Illyria and Paeonia, are solid hoofed like horses or mules. This information was later repeated by Pliny around AD77 (trans. Ernout and Pepin, 1947) and by Buffon during the 18th century (Leclerc de Buffon, 1819). Gesner also described the existence of syndactyle pigs in England ('Anglia'), Belgium and the Netherlands in 'maritimis locis Flandriæ', and further descriptions were made by Linnaeus in 18th century Sweden (Camus, 1783: 686), Struthers (1863) in 19th century Scotland and Bateson (1894) in 19th century France, Scotland, Germany, America and Cuba. In 1745, the Romanian Prince Dimitrice Cantemir was the first to consider porcine syndactyly in greater detail (Vasilescu, 1896). He described a population of syndactyle pigs in a village near Orchei in Bessarabia (probably the modern town of Orhei in Moldova). Cantemir noted that imported cloven-hoofed sows from other provinces gave birth to piglets with 'whole' hoofs after 3 years of breeding with local boar. The same occurred when wild boar interbred with syndactyle domestic sows, thereby suggesting a strong genetic element to the trait. Most early descriptions are concerned with syndactyle populations around the Balkans, although more recent studies have identified the trait in Brazil, Mexico, Texas and Scotland (Kosswig and Ossent, 1936: 325; Wiesner, 1960: 88, Lemus et al., 2003). However, as noted by Darwin (1883b: 424), syndactyly does not always affect pigs across whole populations and can at times appear spontaneously in individuals.

Cornevin (1898) and Vasilescu (1896) carried out the most comprehensive 19th century studies of syndactyly. Vasilescu (1896: 257-267) carried out breeding experiments crossing syndactyle and cloven-hoofed pigs and demonstrated the genetic transmission of syndactyly. Cornevin was particularly interested in the contribution that syndactyle pigs could make to understanding the nature of different porcine breeds. On the basis of the heredity of the trait, as demonstrated by Vasilescu's (1896) breeding experiments, Cornevin defined syndactyle pigs as a separate subspecies, Sus scrofa syndactylus (Cornevin, 1898: 66-67). Linnaeus (1793) had already separated syndactyle pigs Sus monongulus, from the common domestic pig, Sus domesticus vulgaris and the Chinese pig, Sus sinensis, the three taxa together making the domestic pig, Sus domesticus. This emphasises the importance placed on the trait for taxonomy in the past.
Syndactyle pigs have clearly been the focus of substantial debate in the past, and populations have been identified throughout the world from antiquity onwards. However, few syndactyle specimens have ever been recovered (or at least reported on) archaeologically, and consequently, the etiology of the condition and its implications for interpreting past faunal populations have not been debated in zooarchaeology.

\section{Morphology}

There has been substantial debate concerning the morphological characteristics of syndactyle pigs, and evidence suggests that their general appearance is diverse. In observing the Danube population, Cornevin (1898: 133) described them as having certain similarities with wild boar, with some having quite a curly coat, a 'mane' on their neck and being of lesser size and weight than common Romanian pigs. However, Vasilescu (1896: 260) stated that syndactyle pigs he encountered were indistinguishable from clovenhoofed pigs other than in the area of the phalanges. During analysis of an imported South American syndactyle piglet, Ossent (1932: 230) noted that the individual was longer legged, had a more pointed body shape, a longer head and a more angular jaw compared with European breeds.

Evidence from radiography and dissection clearly demonstrates that syndactyle fusion is diverse in character. The first anatomical investigation into the osteological structure of syndactyle pigs that the authors are aware of was undertaken by Cuvier and repeated by Cornevin (1898). On a single limb of a syndactyle pig, Cornevin described two accessory elements that had developed between the second phalanges and the terminal phalanges and stated that the extremity of a third digit had developed a nail, which covered the other two, but with observable traces of the three nails from which it formed (Cornevin, 1898: 134). It was also noted that lateral phalanges remained unaffected. Vasilescu (1896: 261) benefited from carrying out dissection of a different individual and described how the terminal phalanges were fully fused whereas the second phalanges were only fused in the distal half, with the proximal portion being partially united by dense cartilaginous material.

In a study of Mexican Mule Foot pigs, Lemus et al. (2003) described the unusual morphological alteration of second phalanges in association with syndactyle terminal phalanges. As well as being shorter, a third intermediate element was present between the second phalanges and some degree of fusion had occurred. 
$\mathrm{X}$-rays of the Mexican pigs revealed that the syndactyle terminal phalanges also comprised three bones. The addition of an accessory 'phalanx' was also noted by Darwin (1883a: 78) and Ghetie and Dinu (1957) who stated that accessory elements act to unite both the second and terminal pairs of phalanges but have no articular surface. An individual examined through radiography by Leipold and Dennis (1972: 269) exhibited axial fusion of the distal portion of the second phalanges, with neither the first nor terminal phalanges being affected. In addition, Steiner (cited by Wiesner, 1960: 89) has noted that syndactyly can cause full fusion in all three phalanges or combinations thereof as well as at times causing fusion in other bones of the feet. At the other end of the spectrum, radiographs demonstrated that the terminal phalanges of a South American piglet were not fused, in spite of only a single hoof being observable externally (Ossent, 1932: 231). Recent studies on a range of taxa have highlighted the varying degrees of fusion of phalanges (Ger, 1998; Kozin, 2003; Dao et al., 2004). The origin of fusion is thought to be at the distal tip, progressing proximally to the articular surface (Zeitchmann, cited by Wiesner, 1960: 89). Evidence suggests that this is consistent in syndactyle elements in spite of the diverse character of fusion.

Research also indicates that syndactyly is diverse in the way it impacts on soft tissue morphology. Vasilescu (1896: 261) observed no changes in the surrounding ligaments of the individual he dissected, although both associated tendons and muscles were morphologically different. This is also supported in research by Ghetie and Dinu (1957) who noted that the accessory element that united the terminal phalanges was served by special tendons that derived from the tendon of the extensor digitalis communis muscle. In contrast, Zietzschmann (cited by Wiesner, 1960: 89), stated that there is no structural or positional difference in the sinews, blood vessels and nerves of syndactyle and cloven-hoofed pigs. Research on humans suggests that syndactyly has a substantial impact on soft tissue morphology, as it has been shown to be associated with an absence (Resnick, 1942; Soderberg, 1949) or deformity (Walker et al., 1969) of the pectoral muscles. In addition, studies on a range of taxa by Carter (1951), Hill (1962), Iwamoto (1967) and Morris (1971) have demonstrated that numerous muscle anomalies are associated with skeletal defects and that muscles do not develop at all when their point of origin is absent because of skeletal abnormalities. In a study of humans with syndactyle parents, but who had not inherited the condition themselves, De Bie et al. (1979) found that complex patterns of the fingertips (and thus fingerprints) were observable, again demonstrating that the expression of syndactyly may have many stages and is multifarious in character.

It has been suggested that syndactyly in pigs may be advantageous in that affected individuals tend to have fewer problems relating to locomotion (Wiesner, 1960: 88; Arias, 2000: 267) and are thought to be more resistant to swine fever (Arias, 2000: 267) and foot and mouth disease (Ossent, 1932: 231; Wiesner, 1960: 88). In addition, pig farmers in Romania stated that syndactyle pigs yielded superior quality products and greater quantities of meat (Ghetie and Dinu, 1957). These perceived benefits led to such a demand for syndactyle pigs at the turn of the 20th century that breeding stocks could hardly satisfy it (Wiesner, 1960: 89). However, research has demonstrated that syndactyle pigs have no immunity to foot and mouth disease and do not benefit from improved locomotion. They have a restricted gait, causing them to only make small steps, which gives them the appearance of walking on tip toes (Wiesner, 1960: 89). Anomalous syndactyle individuals within a normally developed population at times have associated defects. For example, in one study of porcine syndactyly, Leipold and Dennis (1972) described a syndactyle pig that was 'runty' and in generally poor health, although this could not be explicitly linked to syndactyly.

Evidence suggests that the right forelimb is most frequently affected in pigs (Struthers, 1863; Vasilescu, 1896: 258; Malsburg, cited by Kosswig and Ossent, 1936: 325; Wiesner, 1960: 89). In observing the bones of a syndactyle pig, Struthers (1863) noted that terminal phalanges on all limbs were fully fused, and on the forelimbs, the second phalanges were also fused at their distal end but retained separate proximal articular surfaces, therefore suggesting a tendency to more advanced levels of syndactyly in the forelimb. Breeding experiments on pigs carried out by Vasilescu (1896: 262-265) provided no evidence of gender bias in syndactyly.

\section{Other taxa}

Research on other non-human mammalian species other than cattle remains relatively sparse considering that syndactyly has been described as the most common congenital anomaly of the extremities in many animals (Thompson, 2007: 42-43). Most studies on fauna have been concerned with cattle (Sultan and Bhattacharya, 1949; Eldridge et al., 1951; Motohashi, 1954; Roy, 1959; Farmer and Huston, 1961; Huston et al., 1961, 1969; Grüneberg and Huston, 1968; Adrian et al., 1969; Leipold et al., 1969a, 1969b, 1974; 
Ojo et al., 1975; Baker et al., 1980; Johnson et al., 1980; Barr, 1981; Leipold and Peeples, 1981; Taura et al., 1985; Hart-Elcock et al., 1987; Bargai et al., 1989; Bähr et al., 2004; Drögemüller and Distl, 2006; Agerholm, 2007), although Wiesner (1960: 88) stated that pigs are the most commonly affected domestic animals. Other taxa for which syndactyly has been described include sheep (Dennis and Leipold, 1970), white tailed deer (Rollor, 1993), dogs (Leipold and Guffy, 1973; Dallman and Brown, 1980; Renoy and Balligand, 1991), foxes (Harris, 1975), cats (Hays, 1917; Crummy, 1941; Towle et al., 2007), rabbits (Fujimoto et al., 1958), rats (Warkany and Nelson, 1942), mice (Kadam, 1962; Center, 1966; Stewart and Stewart, 1969), seals (Struthers, 1863: 109), primates (Lapin and Yakoleva, 1963; Primack et al., 1972; French, 1986; Rothschild and Woods, 1992;), wallabies (Lyne, 1953), domestic fowl (Jaap, 1939; Warren, 1950; Hollander and Brumbaugh, 1969) and frogs (Lynch, 1965).

A discussion of research on syndactyly in all of the aforementioned species is well beyond the scope of this paper. However, selected relevant findings from studies on other taxa are presented here. The degree of variability in the fusion of phalanges is further illustrated by Primack et al. (1972: 137) who observed varied morphological alterations in the different limbs of an Indian rhesus monkey. Syndactyly affected limb morphology proximally to the metapodials, with one metacarpal being undeveloped and two metacarpals being fused distally. Fusion affected the proximal phalanges and was associated with misaligned digits and ectrodactyly (the absence of certain bones, in this case the phalanges) with the number of digits ranging from one to four. The manifestation of syndactyly is not always random, and patterns of incidence are evident for some taxa. For example, research has provided evidence that bovine syndactyly most frequently affects the right forelimb (Huston et al., 1961; 1969b; Leipold et al., 1969a). In studying 55 syndactyle cattle, Leipold et al. (1969a) found that the right forelimb was affected in every instance, whereas the left hindlimb was affected in only four individuals. Barr (1981) detailed the order of occurrence of syndactyly, noting that it proceeded from the right forelimb, then the left forelimb, next the right hindlimb and finally the left hindlimb, which was least likely to be affected.

\section{Etiology}

The hereditary nature of syndactyly has become strongly attested to as Cantemir (1745: 92) noted that interbreeding bidactyl sows with syndactyle males led to the birth of piglets with 'whole' hoofs by the third year. The majority of works on the heredity of syndactyly have been concerned with humans (Welg, 1916; Hurlin, 1920; Aksenov and Aksenov, 1927; Devries et al., 1951; Kaul and Bhandari, 1959; Beckman and Widlund, 1962; Eubel et al., 1985; Ghadami et al., 2001; Greuse and Coessens, 2001 and many more). However, other taxa for which the heredity of syndactyly has been demonstrated include cattle (Sultan and Bhattacharya, 1949; Eldridge et al., 1951; Motohashi, 1954; Roy, 1959; Adrian et al., 1969; Leipold et al., 1974; HartElcock et al., 1987; Barr, 1981; Drögemüller and Distl, 2006; Wöhlke et al., 2006; Agerholm, 2007; Drögemüller et al., 2007), mice (Bagg, 1929; Bean, 1929) and rats (Warkany and Nelson,1942). Syndactyly is also known as 'mule foot' in modern cattle and has been found to result from a simple mutation in a single recessive gene. In 1976, it was added to the list of class 1 defects of the American Angus Association (Barr, 1981), after Cantemir (1745), Darwin (1883a), Kosswig and Ossent (1936) and Wiesner (1960) provided further evidence for the heredity of the condition in pigs, with breeding experiments by Vasilescu (1896) providing strong evidence that syndactyly is a dominant genetic trait (see also Detlefsen and Carmichael, 1920; Kalugin and Malsburg, cited by Kosswig and Ossent, 1936: 325). However, according to Brothwell (2008: 120), although the etiology of the condition is congenital in cattle and dogs, it is unconfirmed as such in either pigs or sheep.

In spite of the strong evidence for the hereditary nature of syndactyly, some research has suggested that syndactyly in humans (Warkany, 1944; Nelson et al., 1952) and mice (Kalter and Warkany, 1957) may also be influenced by nutritional deficiency. In addition, research has indicated that the condition may be linked with diabetes in mice (Stewart and Stewart, 1969) and rabbits (Fujimoto et al., 1958) and perhaps with maternal smoking in humans (Honein et al., 2001; Hampton, 2006; Man and Chang, 2006). Experiments in pigs carried out by Ross et al. (1945) also demonstrated nutritional deficiency to be a critical factor in both the occurrence and the severity of syndactyly. In this study, the disorder was commonly associated with a range of other morphological characteristics including vestigial hindlimbs, hypertrophic eyes, kinked tails, talipes, oedema of the hind legs and dermastosis and scurf over the back and ears (ibid: 409-411).

\section{Archaeology}

This abnormality has only been identified in archaeological assemblages in exceptionally rare instances. 
Other than the new specimens described in this paper, the only archaeological porcine example known to the authors is a fully fused pair of terminal pig phalanges from a medieval context at Osborne House, Romsey, UK (Siegel, 1976: 369; Coy, 1986; Brothwell, 2008:

Q1 122), which is described in detail in the succeeding discussions. Harcourt (1979: 158) identified a further example of caprine syndactyly at the Iron Age site of Gussage All Saints in Dorset, England. It is likely that only a fraction of individuals affected by syndactyly would ever be identifiable in the archaeological record, as many may only exhibit soft tissue changes and elements in the early stages of fusion may become separated into their constituent parts through the effects of taphonomic processes. Specimens are described in chronological order, and pertinent features described in the text are indicated with arrows in the respective figures.

\section{Specimen 1}

Specimen 1 was recovered during excavations of a Middle Bronze to Earliest Iron Age settlement with an overlying Early Iron Age midden at Llanmaes, Vale of Glamorgan, South Wales, by Amgueddfa CymruNational Museum Wales in 2004. The faunal assemblage from the site is overwhelmingly dominated by pig bones, with an excess of 8000 fragments having been recovered thus far. This sample includes 168 terminal phalanges, although only two pairs exhibit evidence of syndactyly (see also Specimen 2). Faunal and other archaeological evidence from Llanmaes suggests that people may have converged on the site from the surrounding landscape or further afield. Consequently, it is unlikely that all pigs were husbanded in the immediate locality, and they may represent several populations. The specimens were recovered from different contexts located approximately $4 \mathrm{~m}$ apart and have notable morphological dissimilarities, although these may result from one element deriving from the forelimb and the other from the hindlimb. Stratigraphic information cannot rule out the possibility that they derive from the same individual. It is noteworthy that the majority of pig long bone elements from the site derive from the right forelimb, the same limb which Leipold et al. (1969a) found to be most frequently affected by syndactyly in cattle.

Specimen 1 was recovered from a late Bronze Age quarry hollow, underlying the extensive midden at the site and judging from its size and robusticity, appears to be from an individual of sub-adult or adult age. The example is well preserved, with only slight loss of bone at the distal extremity where the two phalanges fuse (Figure 1). The phalanges are fully fused F1 distally, creating an element with morphological similarities to a perissodactyl terminal phalanx. The proximal aspect also exhibits complete fusion with only shallow linear impressions providing evidence that the elements were ever separate (Figure 1). As the linear impressions must indicate the border of the original phalanx, it is possible to discern their morphological character. The articular surface of the phalanx on the right side of the first image in Figure 1 has a greatly reduced axial facet, whereas the axial facet of the opposing phalanx appears enlarged. The pair exhibits considerable asymmetry.

Radiography of the specimen provided interesting results (Figure 2). This clearly showed the two terminal F2 phalanges, and it is possible that the intervening radioopaque region may represent a supernumerary element, as in the Mexican Mule Foot pigs described by Lemus et al. (2003). The shallow linear fusion lines visible on the proximal articulation provide further evidence for the presence of an intermediate element (Figure 2). The linear impressions are not centrally positioned, as would be expected if the element comprised two equal

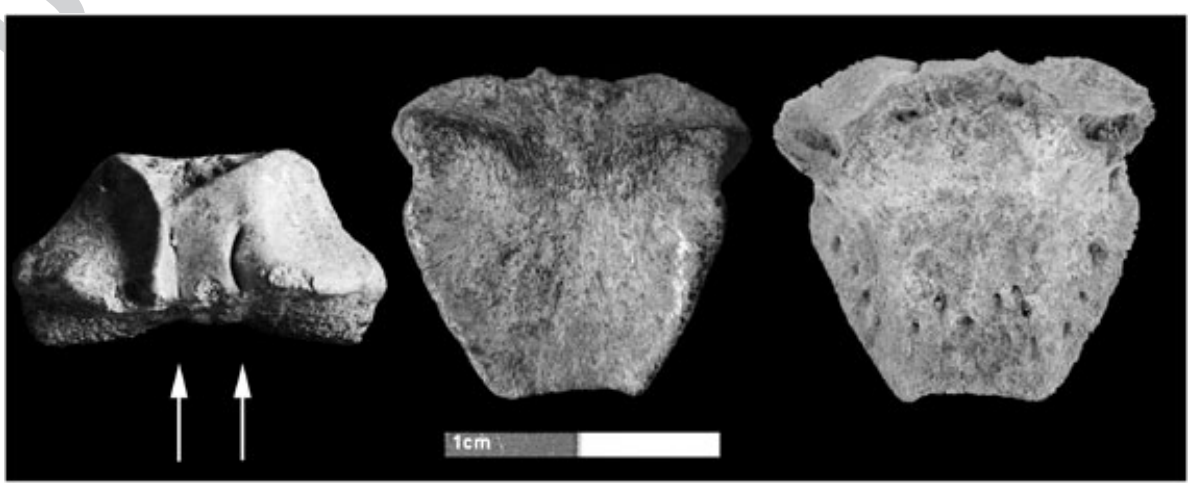

Figure 1. Proximal, plantar and dorsal and views of specimen 1 from Llanmaes. 


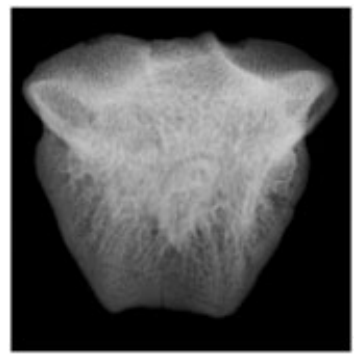

Figure 2. Radiograph showing dorsal-plantar aspect of specimen 1 from Llanmaes. Note the three dense osseous protuberances indicated by radio-opaque peaks.

sized phalanges, but are situated on either side of the supernumerary element. The morphology of the bone also fails to match the triangular shape that would be expected for two fused terminal phalanges. The trapezoidal form may be characteristic of the presence of a third element.

\section{Specimen 2}

Specimen 2 also derives from the later prehistoric midden at Llanmaes and was recovered during the 2008 season of excavation. The element was found in the upper fill of a possible tree throw and is probably late Bronze Age in date. The bone likely derived from a sub-adult or adult individual. The element is well preserved, although a small portion of bone has fragmented where the two phalanges fuse distally. Morphologically, this example is similar to specimen 1 and is F3 again fully fused (Figure 3), although it is somewhat larger and more robust and angular. From the proximal view, the specimen exhibits a somewhat less complete degree of fusion than specimen one (Figure 3). In place of the shallow linear impressions of specimen one is a deeper, more pronounced division that is also observable from the plantar aspect. In addition from the dorsal view, two narrow gullies are observable, which run from the proximal end approximately halfway down the element. It is unknown whether fusion on this specimen has not yet progressed to completion or whether the element derives from a mature individual, and consequently, variation in the degree of fusion is congenitally dictated. The terminal phalanx to the right of the first image in Figure 3 still has a discernibly separate articular surface, but it is morphologically atypical, with a reduced axial facet and an amorphous abaxial facet. By contrast, the articular surface of the other phalanx is difficult to discern. It is morphologically atypical, and a shallow linear impression is suggestive of the phalanx being fused to a much narrower supernumerary element. It appears broadly symmetrical to the separate phalanx but with less evidence of a reduction of the axial facet.

Radiography of specimen 2 revealed similar results to that of specimen 1 . The central zone of the element exhibited the highest density, and the three dense osseous 'peaks' were even more pronounced, both macroscopically and radiographically (Figure 4 ). This F4 is again indicative of the presence of an intermediate 'supernumerary' element that unites the phalanges and accounts for the square distal end of the specimen, which would be pointed if only the two terminal phalanges fused.

\section{Specimen 3}

Specimen 3 is from the early medieval site of Les Chinchettes (Saint-Cyprien, Pyrénées-Orientales) near Perpignan in Roussillon (southern France). The element was found in one of the numerous pits filled during the second half of the 6th century $\mathrm{AD}$ or possibly the beginning of the 7 th century. It derives from a

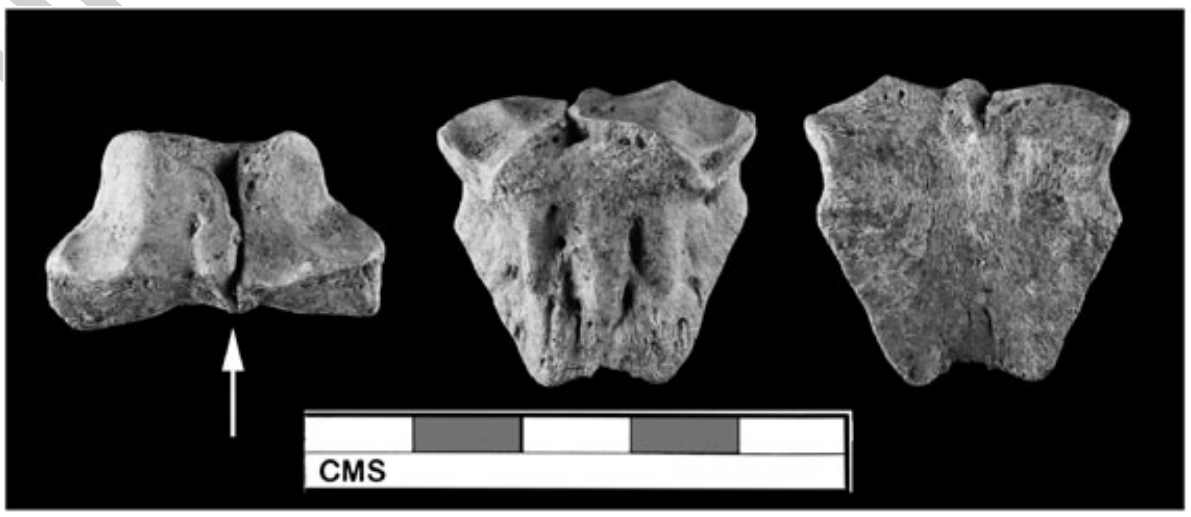

Figure 3. Proximal, plantar and dorsal views of specimen 2 from Llanmaes. 


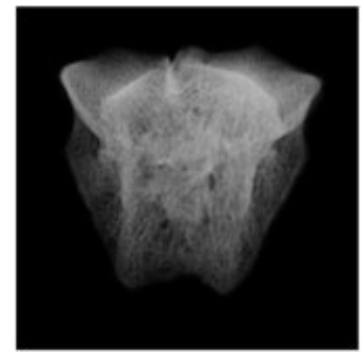

Figure 4. Radiograph showing dorsal-plantar aspect of specimen 2 from Llanmaes. Note the three dense osseous protuberances indicated by radio-opaque peaks.

mature individual. Seven pig terminal phalanges were identified at this site from a number of identifiable speci-

Q3 mens (NISP) of 375. The element exhibits syndactyly of a similar character to specimen 1, with complete

F5 union of the phalanges having been achieved (Figure 5). The level of fusion is even more advanced than that of specimen 1, as there is a complete absence of fusion lines on the proximal articulation. The axial part of the proximal articular surface of each phalanx, normally deeper than the abaxial, is no longer observable, suggesting that the distal articular surfaces of the two associated second phalanges were also modified. In addition, the angle between the proximal surface and the plantar one is more open than in a normal phalanx. The morphology of the articular surface indicates that this element may be similar to specimen 1 and be comprised of three ossified structures, as evidenced by the morphology of the proximal articulation. The articular surface is divided into three distinct segments (Figure 5), suggesting the presence of an intermediate element. The three segments are discernable to a lesser extent from the plantar view. Dorsally, specimen 3 appears more pointed distally, whereas specimen 1 is relatively more square ended. After a macroscopic analysis, this was considered likely to result from the morphology of

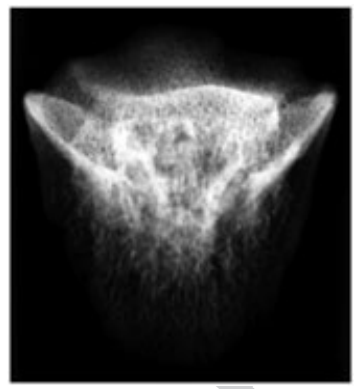

Figure 6. Radiograph showing dorsal-plantar aspect of specimen 3 from Les Chinchettes.

the intermediate element (if present). However, radiographic analysis shows a high degree of homogeneity in the osseous structure without any trace of the supernumerary axial point of ossification (Figure 6). Union is $\mathbf{F 6}$ complete and makes for a fully formed element, not recognised as pathological during analysis, rendering species identification problematic.

\section{Specimen 4}

The fourth syndactyle element was recovered by Oxford Archaeology during excavations at site A on the A2 road scheme. The specimen is from Kent, in South-East England, and derives from a Saxo-Norman pit, which contained two partially complete neonatal pig skeletons. No other pig phalanges were found at site $\mathrm{A}$, the assemblage comprising a NISP of 601 . This specimen is from a neonatal individual and is more poorly preserved than the other examples. The distal edge of the abaxial part of the element has fragmented. The fusion of the phalanges is also of a very different character. Rather than fusion being absolute axially, it is only complete from the plantar aspect (Figure 7). F7 The dorsal view shows an almost complete division with only a thin osseous bridge uniting the elements

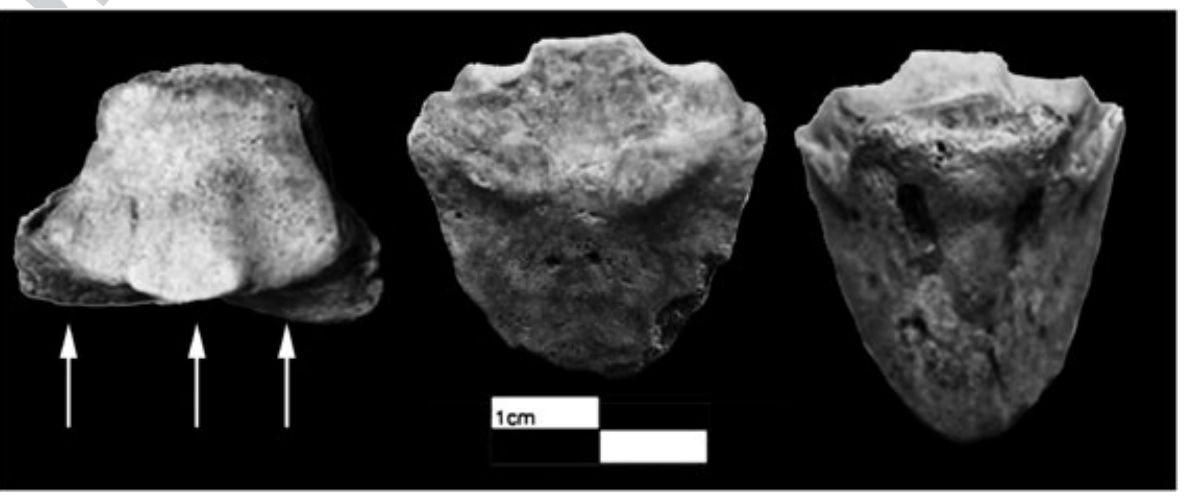

Figure 5. Proximal, plantar and dorsal views of specimen 3 from Les Chinchettes. 


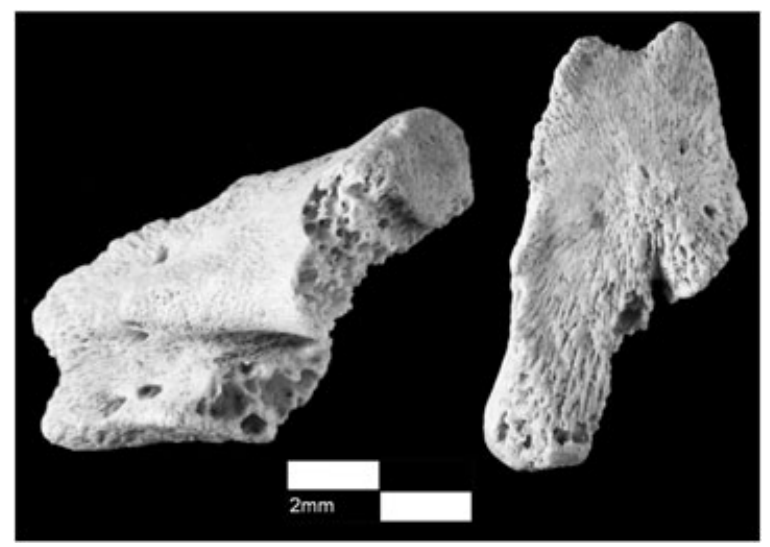

Figure 7. Dorsal and plantar views of specimen 4 from the A2 road scheme in Kent.

on the plantar surface. The character of fusion reveals that the specimen does not comprise of three elements as in specimens 1 and 3, as the central axial area has only a thin osseous join and no third radio-opaque peak was visible radiographically. However, it cannot be discounted that a third element may have existed but may not have united with the phalanges by the time of death. It is possible that this specimen represents an early stage of syndactyly. However, it could also represent a different manifestation of the abnormality. The remainder of the skeleton showed no other abnormalities.

\section{Specimen 5}

The fifth example of a syndactyle terminal phalanx was recovered during excavation of Dunnyneill Island,
Strangford Lough, Co. Down, Northern Ireland, UK, in 2002-2003. This excavation was carried out by the Centre for Archaeological Fieldwork at Queen's University, Belfast, Ireland. There were multiple phases of activity on the island, ranging from the prehistoric to later medieval periods, with this phalanx being recovered from a later medieval context. A total of 26 pig terminal phalanges were identified from this phase, which had a NISP of 2145.

A terminal phalanx was fused to another, smaller element, probably a supernumerary element, similar to those described in specimens 1, 2 and 3 (Figure 8). F8 Dorsally, the two elements are fused along much of the length, but with the extreme distal and proximal ends separate, and a clear division between the two. The plantar surface shows a much greater degree of fusion with only a small region of unfused bone at the extreme proximal and distal ends and with a ridge of bone extending along the length of the line of fusion. When examined from the proximal aspect, we found the elements to be separate, with a complete, unaltered $Q 4$ articular surface observable on the larger phalanx. The articular surface of the smaller element is atypical in form, with a vertical rather than angled aspect. The articular surface of the smaller element is unfortunately damaged $_{i}$ however, the parts present suggest that it does not have the medial ridge found on a normal phalanx. Overall, the articular surface of the pair is asymmetrical, suggesting that another element may also have been originally present abaxial to the reduced bone. If so, this putative phalanx must have been unfused to the syndactyle elements as the abaxial edge

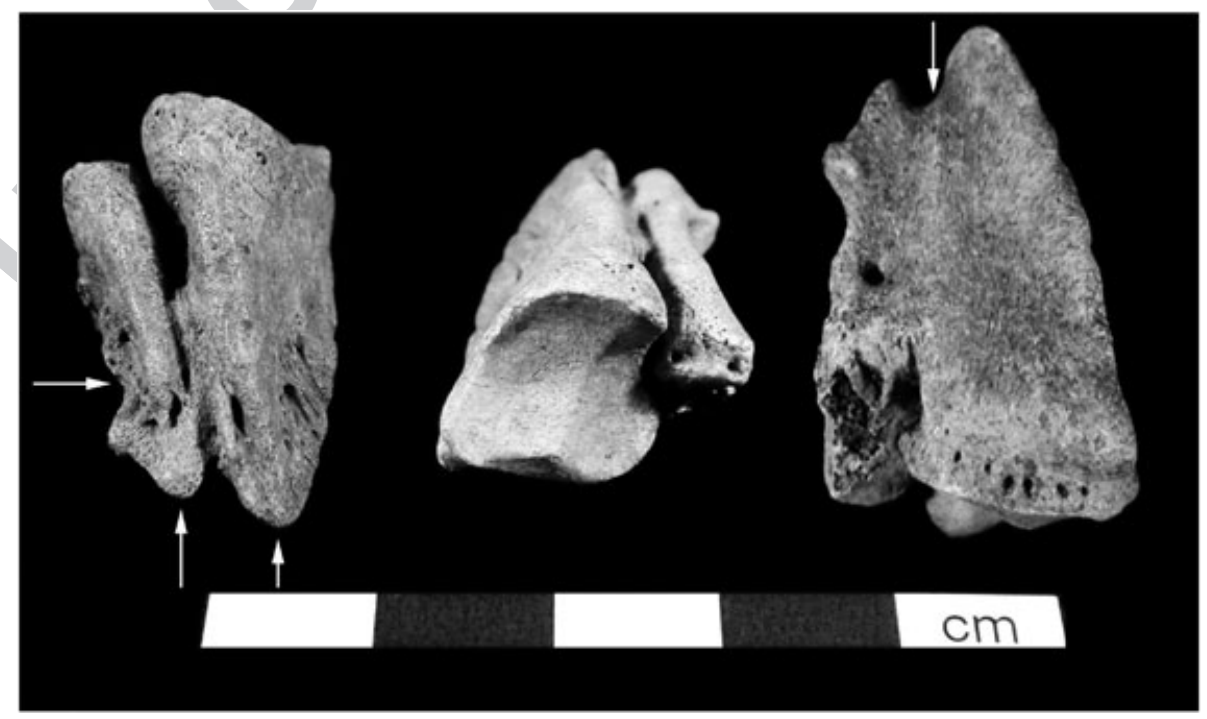

Figure 8. Proximal, plantar and dorsal views of specimen 5 from Dunnyneill, Co. Down. 
of the smaller element shows no evidence of fusion. It would, however, have had to have been of an atypical shape to fit with the fused pair. The shape of the distal end of the fused pair suggests that rather than being pointed or square ended as in the previous examples, if a third abaxial element was present, then this specimen would have had a 'saw-toothed' profile, as at the distal end the abaxial side of the smaller bone shows some evidence of the characteristic flattened hoof edge.

\section{Specimen 6}

The final example of terminal phalanges presented in this paper derives from a medieval context at the site of Osborne House in Romsey, Hampshire, UK. Unlike the other four specimens, this element is not a new discovery and was excavated in the 1970s. However, it has not been previously described in detail with only a solitary photo having been published (Siegel, 1976: 369). Different classes of phalanges were not differentiated in data tables in the unpublished faunal report on Osborne House (Coy, 1986), but only two pig phalanges are noted in the entire assemblage (NISP = 858). Although somewhat less robust than specimens $1-3$, this specimen is large enough to suggest that it is from an individual of at least sub-adult age. However, it is slightly smaller and lighter and may therefore represent a younger individual. This element exhibits a far less complete degree of fusion than the other mature examples where both phalanges are] present and radiography is not necessary for the identification

F9 of the supernumerary element (Figure 9). The element appears quite narrow $(3.3 \mathrm{~mm} \max )$ from the dorsal aspect but is somewhat broader in the plantar aspect with a 5.9-mm-wide osseous protuberance being slightly distally displaced from the proximal articular surface. Fusion is extensive enough to obscure the exact form of the extra element, although it appears to be an amorphous, elongated element quite unlike other phalanges. The articular surfaces of the two terminal phalanges are not symmetrical to each other, and both show morphological anomalies. The phalanx to the left of the first picture in Figure 9 shows considerable alteration, with the axial facet being reduced and flattened, with almost no concavity observable. The phalanx to the right of the picture shows a greatly reduced abaxial facet.

Radiography provides further detail as to the morphology of the supernumerary element. It appears as a thin protuberance of bone, which tapers to a point at its distal end (Figure 10). This supernumerary elem- F10 ent, which may represent ossified fibrocartilage, was presumably absorbed into the homogeneous structure of the bone in specimen 3, which is considered to be representative of a more advanced stage of syndactyly. The character of the element supports Steiner's (cited by Wiesner, 1960: 89) view that fusion originates at the distal end and progresses proximally to the point of articulation with the second phalanges.

\section{Second phalanges: specimens 7 and 8}

In addition to the terminal phalanges described above, two second phalanges from Dunnyneill Island may originally have been syndactyle with other missing phalanges. These were recovered from a later medieval context and from topsoil. There were 31 pig second phalanges recovered from the later medieval phase $(N I S P=2145)$ and 14 from topsoil (NISP $=1052)$. The stratified example (specimen 8) was from the context immediately above that from which specimen 5 was

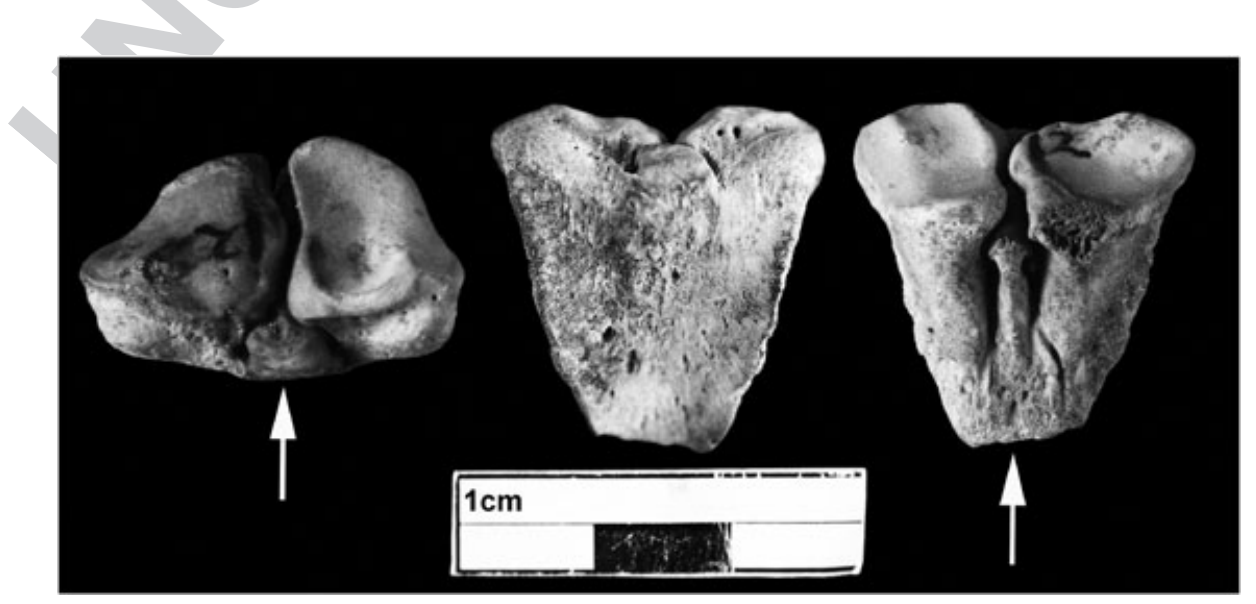

Figure 9. Proximal, plantar and dorsal views of specimen 6 from Osborne House, Romsey. 


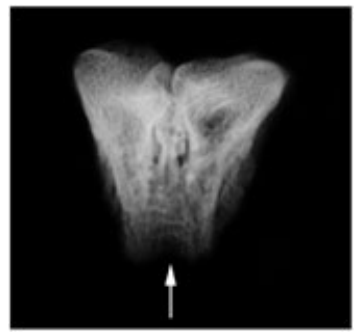

Figure 10. Radiograph showing dorsal-plantar aspect of specimen 6 from Osborne House, Romsey.

recovered, whereas the topsoil example (specimen 7) came from the adjacent cutting. The two phalanges were not fused to each other and were of different sizes, demonstrating that they were not adjacent. It is possible that they were from different limbs of a single individual or from two individuals, and it cannot be entirely discounted that one or both could have come from the individual with the syndactyle terminal phalanges described as specimen 5 , but in neither case do they articulate with that element. Both exhibited a split in the distal articular surface similar to a type 2 articular depression defined by Baker and Brothwell (1980: 41, 109-14) in cattle and red deer, believed to be congenital in origin.

Specimen 7 exhibited an exostosis on the axial side, extending from the distal end towards the proximal

F11 (Figure 11). When we viewed this from the axial side, this appeared as a semicircular area extending axially beyond the line of the surrounding bone. This area measured a maximum of c. $0.5 \mathrm{~mm}$ medio-laterally, $13.7 \mathrm{~mm}$ proximo-distally and $12.3 \mathrm{~mm}$ in a dorsoplantar direction. When we viewed this from the distal end, the phalanx had an anomalous shape because, as well as the type 2 anomaly, the axial margin was straight rather than convex and it appeared to have been butted directly against the adjacent phalanx. By contrast, for the remainder of the semicircular extent, the line of the exostosis extended beyond the line of the unaffected bone by up to c. $0.5 \mathrm{~mm}$. The centre of the affected area appeared to be a broken surface of normal trabecular bone, except at the proximal extent, where it was fringed by an oval-shaped area of smooth bone measuring c. $3 \mathrm{~mm}$ proximo-distally by c. $7.4 \mathrm{~mm}$ in a dorso-plantar direction. The over-riding impression given by the phalanx was that it had been broken away from an adjacent syndactyle phalanx.

Specimen 8 exhibited a similar pathology. When we viewed it from the axial side, the affected area measured a maximum of c. $0.5 \mathrm{~mm}$ medio-laterally, $9.1 \mathrm{~mm}$ proximo-distally and $13.2 \mathrm{~mm}$ in a dorso-plantar direction. This area again extended in a semicircular shape from the distal end on the axial side of the phalanx (Figure 12). Viewed from the distal end, the phalanx F12 had an anomalous shape because, as well as the type 2 anomaly, the axial margin was straight rather than convex and it appeared to have been butted directly against the adjacent phalanx. By contrast, for the remainder of the semicircular extent, the line of the exostosis extended beyond the line of the unaffected bone by up to c. $0.5 \mathrm{~mm}$. In this case, however, the circumference of the affected area was surrounded by a smooth ring of bone measuring up to $3 \mathrm{~mm}$ in width, but only c. $1 \mathrm{~mm}$ at the distal end. The centre of this semicircular area was slightly depressed relative to the encircling ring, and in this area, trabecular bone was also

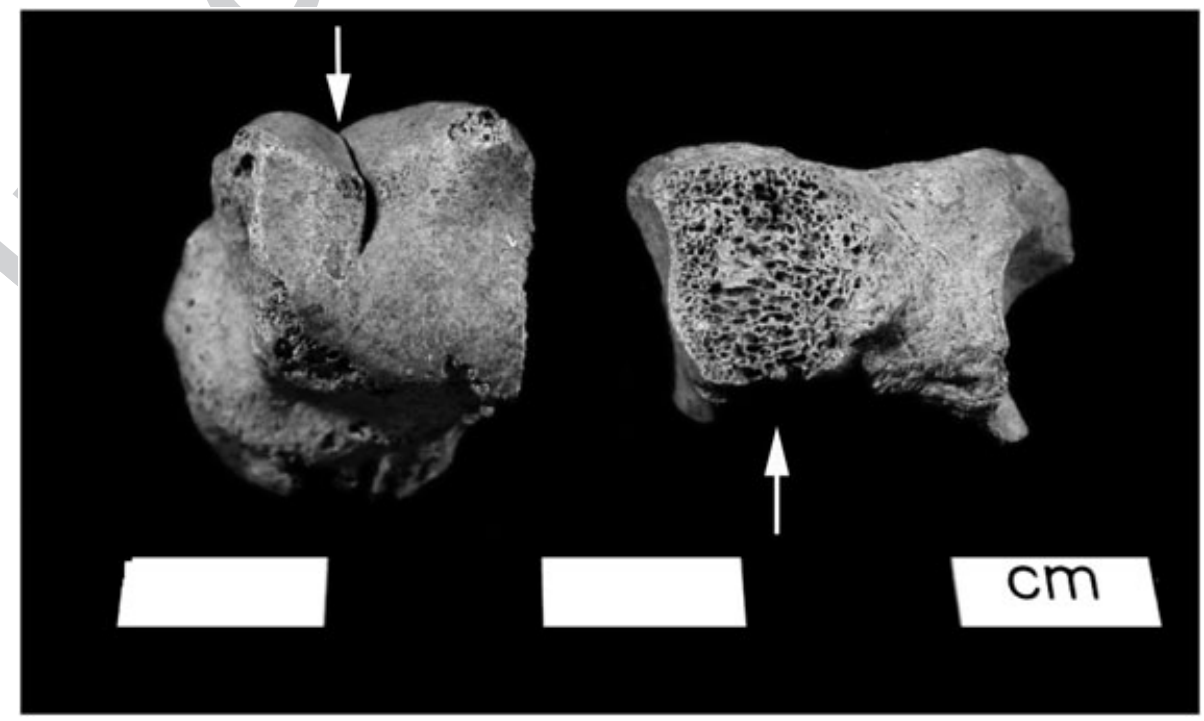

Figure 11. Distal and axial views of specimen 7, second phalanx from Dunnyneill Co. Down. 


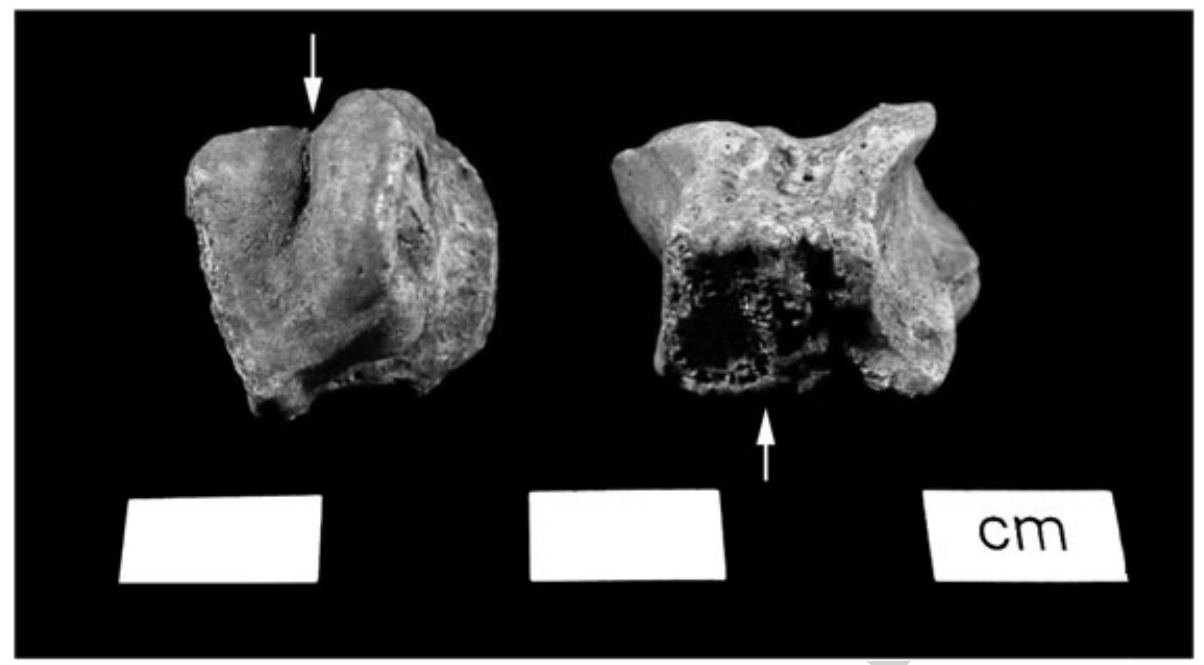

Figure 12. Distal and axial views of specimen 8, second phalanx from Dunnyneill Co. Down.

visible. Unlike specimen 7, the surface of this trabecular bone was slightly smooth because of remodelling of the bone, so it did not appear to have been broken away directly from a syndactyle element. The exostosis may have been due to trauma caused by frictionagainst the adjacent phalanx because of the anomalous shape of the bone. It is more likely, however, that this had been a point of partial or potential fusion of the phalanx with a missing syndactyle phalanx.

\section{Conclusion}

This paper adds to the sparse corpus of research on the occurrence of porcine syndactyly in the archaeological record and presents a review of veterinary and zoological literature on the subject. The specimens of fused terminal phalanges from mature animals are relatively similar and fit Aristotle's early description of the abnormality. No archaeological examples of actual fused second phalanges are known to the authors; however, two examples from a single site have been presented in which there is evidence that fusion may have occurred, with subsequent ante mortem and post mortem breakage. All of the described specimens of terminal phalanges are likely to represent isolated syndactyle individuals from different populations. They exhibit several different stages in the fusion of phalanges as described in modern studies of syndactyly: beginning at the cranio-ventral tip, then extending on the plantar face and completing fusion at the dorsocaudal extremity.

Fusion does not occur through the simple joining of the two bones as in ruminant metapodials but through an intermediate ossified structure at the axial midline.
This may represent the ossification of a fibrocartilage bridge between the phalanges, as described in some clinical observations. This ossified structure is present in four of the six specimens and may be present in a fifth. The other example from a neonatal animal displays a large dorsal gap between the two phalanges. This gap is likely to represent the location of this intermediate bone that had not yet fused and has been lost post-deposition. Further study is required to determine the exact nature of the ossified structure, and it is at present unclear whether 'supernumerary phalanx' is an appropriate term by which to define it. Although the phalanx of Les Chinchettes (specimen 3 ) has a third proximal articular facet, suggestive of an intermediate phalanx, formation of this facet may result as a response to joint movements, and therefore, 'ossified structure' is considered a more appropriate term, as no element was observable in radiographs of the specimen. The example from Dunnyneill also has a proximal articular facet, and in this case, the distal end of the bone is pointed. In this example, there may not have been a third terminal element present, although the shape of the articular surface suggests that an additional unfused element may have existed in the living animal.

The review of previous research and the analysis of the archaeological specimens demonstrate that the gross morphology of syndactyle elements is diverse. Variation may result from congenitally dictated differences in the manifestation of the abnormality. However, the degree of fusion may also relate to the age of the individual, with fusion progressing throughout life. The perfect symmetry of the Les Chinchettes element (specimen 3) demonstrates complete fusion. Specimen 1 and to a lesser extent specimen 2 (both from Llanmaes) also show advanced stages 
of syndactyly, if it is assumed that fusion progresses to completion. By contrast, the Osborne House element (specimen 6) is far less complete, and specimens 4 (A2) and 5 (Dunnyneill Island) also appear to be at an early stage of syndactyly.

Systematic analyses on a range of living populations are required to elucidate the causes of variation, although the fact that two specimens that derive from younger individuals (specimens 4 and 6) exhibit less complete fusion suggests that union progresses to completion throughout life.

Syndactyly in pigs can occur across either whole populations or breeding groups with some evidence suggesting that affected pigs tend to have morphological similarities to wild boar. Alternatively, it may occur spontaneously in individuals. This again emphasises the multifarious nature of the condition. A logical extension of the research would be to undertake genetic analysis of the specimens and compare them with existing genetic data for pigs. This has the potential to identify any link with areas described as having syndactyle populations.

The relatively common identification of syndactyle pigs from antiquity to the modern day, both as individuals and populations, suggests that the condition may have been more common in the past than has previously been recognised. The recording of several new archaeological specimens within a short time by the authors is coincidental, but only a single other published archaeological pig specimen is known of, therefore hinting that the condition may sometimes have gone unnoticed. It is perhaps more likely that examples have rather been omitted from publication, perhaps because of the absence of a corpus of research on syndactyly in the past and the resultant difficulty in putting specimens in their temporal, geographical and palaeopathological context. This paper therefore aims to provide a starting point from which to improve understanding of the prevalence, geographical and temporal distribution and archaeological implications of syndactyly in the past.

\section{Acknowledgements}

We are grateful to Phil Parkes and Martine BenezechProuvot for assistance with radiography and to David Allen, Kay Ainsworth, Don Brothwell and the late Jennie Coy for their help in locating the Osborne House specimen. Thanks are also due to Adam Gwilt, Jerôme Kotarba, Philip Macdonald and Finbar McCormick for contextual information. Thanks also go to Ian
Dennis for assistance with image formatting and to Jacqui Mulville and Adrienne Powell for their insightful comments on earlier drafts of this paper. Finally, we are obliged to the two anonymous reviewers for their thoughtful remarks on the original manuscript.

\section{References}

Adrian RW, Trotter DM, Leipold HW, Huston K. 1969. Anatomy of hereditary bovine syndactylism. IV. Neurology. Journal of Dairy Science 52: 1441-1444.

Agerholm JS. 2007. Inherited disorders in Danish cattle. APMIS 115: 1-76.

Aksenov VV, Aksenov BB. 1927. Inheritance of syndactyly. Russian Journal of Eugenics 5: 105-112.

Alvord RM. 1947. Zygodactyly and associated variations in a Utah family. Journal of Heredity 38: 49-53.

Arias DF. 2000. El cerdo Sinda colombiano. Memoria $V$ Congreso Iberoamericano de Razas Autóctonas y Criollas. La Habana, Cuba. pp. 267.

Bagg HJ. 1929. Hereditary abnormalities of the limbs, their origin and transmission. II. A morphological study with special reference to the etiology of club-feet, syndactylism, hypodactylism, and congenital amputation in the descendants of x-rayed mice. The American Journal of Anatomy 43: 167-219.

Bähr C, Drögemüller C, Distl O. 2004. Case report: Syndactyly in German Holstein calves. Deutsche Tieraerztliche Wochenschrift 111 : 473-476.

Baker J, Brothwell D. 1980. Animal Diseases in Archaeology. Academic Press: London.

Baker RD, Snider GW, Leipold HE, Johnson JL. 1980. Embryo transfer tests for bovine syndactyly. Theriogenology 13: 87-87.

Bargai U, Pharr JW, Morgan JP. 1989. Bovine Radiology. Iowa University Press: Ames, IA.

Barr M. 1981. Syndactyly. Angus Journal January: 34-35.

Bateson W. 1894. Materials for the Study of Variation Treated with Especial Regard to Discontinuity in the Origin of Species. MacMillan and Co.: London.

Bean AM. 1929. A morphological analysis of the foot abnormalities occurring in the descendants of X-rayed mice. The American Journal of Anatomy 43: 221-246.

Beckman L, Widlund L. 1962. On inheritance of poly- and syndactylies in man. Acta Geneticae Medicae et Gemellologiae 11: 43-54.

Brothwell D. 2008. Radiography in the service of zoopaleopathology. Paleoradiology, R Chhem, D Brothwell (eds.). Springer: New York; 119-143.

Camus AG. 1783. Notes sur l'Histoire des Animaux d'Aristote. La Veuve Desaint: Paris.

Cantemir D. 1745. Letters on Moldavia. Privately published.

Carter TC. 1951. The genetics of luxate mice. I. Morphological abnormalities of heterozygotes and homozygotes. Journal of Genetics 50: 277-299. 
Center EM. 1966. Genetical and embryological studies of jt form of syndactylism in mouse. Genetical Research 8: $33-40$.

Cornevin C. 1898. Les Porcs. Librairie J.-B. Baillière et fils: Paris.

Coy J. 1986. Animal bones from excavations at Osborne House, Romsey RII 1972. Unpublished Report to the Ancient Monuments Laboratory no. 4917.

Crummy PJ. 1941. A case of bilateral syndactyly in the manus of Felis domesticus. Proceedings of the Pennsylvania Academy of Sciences 15: 155-159.

Cuvier G. 1805. Lecons d'Anatomie Comparee. Crochard: Paris.

Dallman MJ, Brown RE. 1980. Syndactyly in the dog. Canine Practice 7: 21-24.

Dao KD, Shin AY, Billings A, Oberg KC, Wood VE. 2004. Surgical treatment of congenital syndactyly of the hand. Journal American Academic Orthopedic Surgery 12: 39-48.

Darwin C. 1883a. The Variation of Animals and Plants under Domestication, Vol. I, 2nd ed. D. Appleton \& Co.: New York.

Darwin C. 1883b. The Variation of Animals and Plants under Domestication, Vol. II, 2nd ed. D. Appleton \& Co.: New York.

De Bie S, Matton M, Van Hoorde P, Van Laethem J. 1979. Aberrant dermatoglyphic findings in unaffected relatives of syndactyly patients. Acta Anthropogenetica 3: 1-12.

Dennis SM, Leipold HW. 1970. Syndactylism in a neonatal lamb. The Cornell Veterinarian 60: 23.

Detlefsen JA, Carmichael WJ. 1920. Inheritance of syndactylism, black, and dilution in swine. Journal of Agricultural Research 20: 595-604.

Devries A, Matoth Y, Shamir Z. 1951. Familial congenital labile factor deficiency with syndactylism - investigation on the mode of action of the labile factor. Acta Haematologica 5: 129-142.

Drögemüller C, Distl O. 2006. Genetic analysis of syndactyly in German Holstein cattle. Veterinary Journal 171: 120-125.

Drögemüller C, Leeb T, Harlizius B, Tammen I, Distl O, Höltershinken M, Gentile A, Duchesne A, Eggen A. 2007. Congenital syndactyly in cattle: Four novel mutations in the low density lipoprotein receptor-related protein 4 gene (lrp4). BMC Genetics 8.

Eldridge FE, Smith WH, McLeod WM. 1951. Syndactylism in Holstein-Friesian cattle-Its inheritance, description and occurrence. Journal of Heredity 42: 241-250.

Ernout A, Pepin R. 1947. Translation of, Pliny the Elder Naturalis Historia, vol XI. Les Belles letters: Paris.

Eubel R, Klose L, Mahrle G. 1985. Hereditary sclerodactyly and syndactyly. Hautarzt 36: 302-304.

Farmer EL, Huston K. 1961. Physiological aberrations in syndactylous cattle. Journal of Animal Science 20: 970.

French JM. 1986. Ectrodactyly and syndactyly in a common marmoset (Callitbrix jaccbus). Laboratory Animals 20: $49-50$.

Fujimoto S, Sumi T, Kuzukawa S, Tonoike H, Miyoshi T, Nakamura S. 1958. The genesis of experimental anomalies. Fetal anomalies in reference to experimental diabetes in rabbit. Journal of Osaka City Medical Center 7: 62-66.
Ger E. 1998. Syndactyly. Congenital Malformation of the Hand and Forearm, D Buck-Gramcko (ed.). Churchill Livingstone: London; 131-141.

Ghadami M, Majidzadeh K, Haerian BS, Damavandi E, Yamada K, Pasallar P, Najafi MT, Nishimura G, Tomita HA, Yoshiura KI, Niikawa N. 2001. Confirmation of genetic homogeneity of syndactyly type 1 in an Iranian family. American Journal of Medical Genetics 104: 147-151.

Ghetie V, Dinu M. 1957. Investigations on the monodactylous hog of Rumania. Revue de Biologie (Rumania) 2: 319-332.

Goodrich ES. 1935. Syndactyly in marsupials. Proceedings of the Zoological Society of London 1935: 175-178.

Greuse M, Coessens BC. 2001. Congenital syndactyly: Defatting facilitates closure without skin graft. Journal of Hand Surgery-American Volume 26a: 589-594.

Groves EWH. 1913. An unusual case of syndactylism. British Journal of Surgery 1: 143.

Grüneberg H, Huston K. 1968. Development of bovine syndactylism. Journal of Embryology and Experimental Morphology 19: 251-259.

Hampton T. 2006. Prenatal smoking linked to digit defects. Journal of the American Medical Association 295: 879-879.

Harcourt RA. 1979. The animal bones. Gussage All Saints: An Iron Age Settlement in Dorset, GJ Wainwright (ed.). Her Majesty's Stationary Office: London; 150-160.

Harris S. 1975. Syndactyly in red fox, Vulpes vulpes. Journal of Zoology 176: 282-287.

Hart-Elcock L, Leipold HW, Baker R. 1987. Hereditary bovine syndactyly-Diagnosis in bovine fetuses. Veterinary Patbology 24: 140-147.

Hays GP. 1917. A case of a syndactylous cat. Journal of Morphology 30: 65-82.

Hill WCO. 1962. Lobster-claw deformity in a drill. Bibliograpbia Primatologica I: 239-251.

Hollander W, Brumbaugh J. 1969. Web-foot or syndactylism in fowl. Poultry Science 48: 1408-1413.

Honein MA, Paulozzi LJ, Watkins ML. 2001. Maternal smoking and birth defects: Validity of birth certificate data for effect estimation. Public Healtb Reports 116 : 327-335.

Hurlin RG. 1920. A case of inherited syndactyly in man. Journal of Heredity 11:334-335.

Huston K, Leipold HW, Trotter DM, Adrian RW, Dennis SM. 1969. Osteologic observations on syndactylous Holstein-Friesian cattle. Journal of Dairy Science 52: 922-923.

Huston K, Mudge JW, Eldridge FE. 1961. Genetics of syndactylism in cattle. Journal of Dairy Science 44: 1197.

Iwamoto M. 1967. Morphological observations on the congenital malformation of limbs in the Japanese monkey. Primates 8: 247-270.

Jaap R. 1939. Brachydactyly and syndactyly in ptilopod domestic fowl, Gallus domesticus. Proceedings of the Oklaboma Academy of Sciences 19: 27-29.

Johnson JL, Leipold HW, Snider GW, Baker RD. 1980. Progeny testing for bovine syndactyly. Journal of the American Veterinary Medical Association 176: 549-550. 
Kadam KM. 1962. Genetical studies on skeleton of mouse. XXXI. Muscular anatomy of syndactylism and oligosyndactylism. Genetical Research 3: 139-156.

Kalter H, Warkany J. 1957. Congenital malformations in inbred strains of mice induced by riboflavin-deficient, galactoflavin containing diets. The Journal of Experimental Zoology 136: 531-565.

Kaul KK, Bhandari NR. 1959. Polydactylo-syndactylism in seven generations. Indian Journal of Pediatrics 26: 18-20.

Kosswig C, Ossent HP. 1936. Syndaktylie einhufiger Schweine und weitere Ergiinzungen zur Vererbung der Schweinefarben. Der Zü̈bter 8: 324-329.

Kozin SH. 2003. Current concepts review: Upper-extremity congenital anomalies. Journal of Bone and Joint Surgery 85: 1564-1576.

Lapin BA, Yakoleva LA. 1963. Comparative Pathology in Monkeys. Thomas Springfield: Illinois.

Lauschke H. 1988. Foot-like congenital macrodactyly with syndactyly of the hand. Journal of Hand Surgery 13: 353-355.

Q5 Leclerc de Buffon G-L. 1819. Histoire Naturelle. Quadrupèdes. Du cochon, du cochon de Siam et du sanglier. Ouevres Complètes de Buffon mises en ordre par Lacépède, 2e édition, Rapet (ed). tome 12: Paris; 188.

Leipold HW, Dennis SM. 1972. Syndactyly in a pig. The Cornell Veterinarian 62: 269-273.

Leipold HW, Guffy MM. 1973. Syndactyly in a German Shepherd dog. Veterinary Medicine, Small Animal Clinician 68: 910-911.

Leipold HW, Peeples JG. 1981. Progeny testing for bovine syndactyly. Journal of the American Veterinary Medical Association 179: 69-70.

Leipold HW, Adrian RW, Huston K, Trotter DM, Dennis SM, Guffy MM. 1969a. Anatomy of hereditary bovine syndactylism. I. Osteology. Journal of Dairy Science 52: 1422-1431.

Leipold HW, Dennis SM, Huston K, Dayton AD. 1974. Hereditary bovine syndactyly 2. Hyperthermia. Journal of Dairy Science 57: 1401-1409.

Leipold HW, Huston K, Guffy MM, Dennis SM. 1969b. Syndactyly in an Aberdeen-Angus calf. American Journal of Veterinary Research 30: 1685.

Lemus FC, Alonso MR, Alonso-Spilsbury M, Ramírez NR. 2003. Morphologic characteristics in Mexican native pigs. Archivos de Zootecnia 52: 105-108.

Linnaeus C. 1793. Système de la Nature. (French translation by Vanderstegen), Brussels.

Lynch JD. 1965. Apparent syndactyly in a Mexican frog [Rana palmipes]. Journal of the Obio Herpetological Society 5: 57 .

Lyne AG. 1953. Syndactyly in the manus of a marsupial. Papers and Proceedings of the Royal Society of Tasmania 87: 31-32.

Man LX, Chang B. 2006. Maternal cigarette smoking during pregnancy increases the risk of having a child with a congenital digital anomaly. Plastic and Reconstructive Surgery 117: 301-308.

Miklíková Z, Thomas R (eds.). 2008. Proceedings of the International Conference of the Animal Palaeopathology Working Group (APWG) of the International Council for Archaeozoology (ICAZ).
Nitra, 23-24 September 2004. B.A.R. International Series no. 1844. Archaeopress: Oxford.

Morris LN. 1971. Spontaneous congenital limb malformations in nonhuman primates: A review of the literature. Teratology 4: 335-342.

Motohashi H. 1954. On twenty-six cases of syndactylous anomaly in the Nipponese improved cattle. Transactions of the Tottori Society for Agricultural Science 10: 212-236.

Nelson MM, Asling W, Evans HM. 1952. Production of multiple congenital abnormalities in young by maternal pteroylglutamic acid deficiency during gestation. Journal of Nutrition 48: 61-79.

Ojo SA, Leipold HW, Guffy MM, Hibbs CM. 1975. Syndactyly in Holstein-Friesian, Hereford, and crossbred Chianina cattle. Journal of the American Veterinary Medical Association 166: 607-609.

Ossent HP. 1932. Einhufige schweine. Der Züchter 4: 230-231.

Partington CF (ed.). 1835. The British Cyclopadia of the Arts, Sciences, Geography, Natural History and Biograpby I. W.M.S. Orr \& Co: London.

Peck AL. 1965. Translation of Aristotle, The History of Animals II. William Heinemann Ltd: London.

Primack A, Young D, Homan E. 1972. Syndactyly in a rhesusmonkey-Case report. Teratology 5: 137-141.

Renoy BP, Balligand M. 1991. A case of syndactylous dog. Annales de Médecine Vétérinaire 135: 43-44.

Resnick E. 1942. Congenital unilateral absence of the pectoral muscles often associated with syndactylism. Journal of Bone and Joint Surgery 24: 925-928.

Rollor EA. 1993. Syndactylism and brachygnathia in a white-tailed deer. Journal of Wildlife Diseases 29: 618-619.

Ross OB, Phillips PH, Bohstedt G, Cunha TJ. 1945. Congenital malformations, syndactylism, talipes, and paralysis agitans of nutritional origin in swine. Journal of the American Veterinary Medical Association 106: 370-375.

Rothschild BM, Woods RJ. 1992. Erosive arthritis and spondyloarthropathy in old world primates. American Journal of Pbysical Anthropology 88: 389-400.

Roy NC. 1959. Congenital defects, lethal and sublethal factors in cattle and buffalos in India. The Indian Veterinary Journal 36: 531-536.

Scott W. 1933. Syndactylism with variations. Journal of Heredity 24: 241-243.

Siegel J. 1976. Animal palaeopathology: Possibilities and problems. Journal of Archaeological Science 3: 349-384.

Soderberg BN. 1949. Congenital absence of the pectoral muscle and syndactylism-A deformity association sometimes overlooked. Plastic and Reconstructive Surgery 4: 434-438.

Stewart AD, Stewart J. 1969. Studies on syndrome of diabetes insipidus associated with oligosyndactyly in mice. American Journal of Pbysiology 217: 1191-1198.

Stiles KA, Hawkins DA. 1946. The inheritance of zygodactyly. Journal of Heredity 37: 16-18.

Struthers J. 1863. On variation in the number of fingers and toes, and in the number of phalanges, in man. Edinburgb New Pbilosopbical Journal 18: 83-111. 
Sultan S, Bhattacharya P. 1949. Inheritance of syndactylism in Hariana breed of cattle. Indian Journal of Veterinary Science and Animal Husbandry 19: 153-159.

Swainson W. 1836. On the Natural History and Classification of Birds. Longman: London.

Q6 Taura Y, Takeuchi A, Uchino T. 1985. Radiography of syndactylous limbs of cattle. Bulletin of the Faculty of Agriculture Kagoshima University: 97-106.

Thompson K. 2007. Bones and joints. Jubb, Kennedy and Palmer's Patbology of Domestic Mammals, Vol. 1, MG Maxie (ed.). Elsevier Saunders: Philadelphia, 1-184.

Towle HA, Blevins WE, Tuer LR, Breur GJ. 2007. Syndactyly in a litter of cats. The Journal of Small Animal Practice 48: 292-296.

Vasilescu C. 1896. Coup d'œil sur l'existence des Porcs monodactyles. Journal de Médecine Vétérinaire et de Zootechnie 17: 257-267.

Walker JC, Meijer R, Aranda D. 1969. Syndactylism with deformity of pectoralis muscle. Polands syndrome. Journal of Pediatric Surgery 4: 569-572.
Warkany J. 1944. Congenital malformations induced by maternal nutritional deficiency. Journal of Pediatrics 25: 476-480.

Warkany J, Nelson RC. 1942. Experimental production of congenital skeletal abnormalities in the offspring of rats fed a deficient diet. The American Journal of Roentgenology and Radium Therapy 47: 889-893.

Warren DC. 1950. Syndactylism in the chicken. Journal of Heredity 41: 31-34.

Welg C. 1916. A case of hereditary syndactyly. Lancet 2: 434-434.

Whewell W. 1840. The Philosophy of the Inductive Sciences, Founded on their History. J.W. Parker: London.

Wiesner E. 1960. Die Erbschäden der Landwirtschaftlichen Nutztiere. Fisher: Jena.

Wöhlke A, Kuiper H, Distl O, Drögemüller C. 2006. The bovine aristaless-like homeobox 4 (alx4) as a candidate gene for syndactyly. Cytogenetic and Genome Research 115 : $123-128$. 


\section{Author Query Form}

\section{Journal: International Journal of Osteoarchaeology}

\section{Article: oa_1260}

Dear Author,

During the copyediting of your paper, the following queries arose. Please respond to these by annotating your proofs with the necessary changes/additions.

- If you intend to annotate your proof electronically, please refer to the E-annotation guidelines.

- If you intend to annotate your proof by means of hard-copy mark-up, please refer to the proof mark-up symbols guidelines. If manually writing corrections on your proof and returning it by fax, do not write too close to the edge of the paper. Please remember that illegible mark-ups may delay publication.

Whether you opt for hard-copy or electronic annotation of your proofs, we recommend that you provide additional clarification of answers to queries by entering your answers on the query sheet, in addition to the text mark-up.

\begin{tabular}{|c|l|c|}
\hline Query No. & \multicolumn{1}{|c|}{ Query } & Remark \\
\hline Q1 & $\begin{array}{l}\text { AUTHOR: "described in detail below" has been changed to "described in detail in the } \\
\text { succeeding discussions". Please check if appropriate. }\end{array}$ & \\
\hline Q2 & AUTHOR: Please check if section titles are correctly presented. & \\
\hline Q3 & $\begin{array}{l}\text { AUTHOR: Number of identifiable specimens. Is this the correct definition for NISP? } \\
\text { Please change if this is incorrect. }\end{array}$ & \\
\hline Q4 & $\begin{array}{l}\text { AUTHOR: "Examined from the proximal aspect the elements are separate" has been } \\
\text { changed to "When examined from the proximal aspect, we found the elements to be } \\
\text { separate". Please confirm the validity of the changes. }\end{array}$ & \\
\hline Q5 & AUTHOR: Please check captured author if correct. & \\
\hline Q6 & AUTHOR: Please provide volume number. & \\
\hline
\end{tabular}




\section{USING E-ANNOTATION TOOLS FOR ELECTRONIC PROOF CORRECTION}

\section{Required Software}

Adobe Acrobat Professional or Acrobat Reader (version 7.0 or above) is required to e-annotate PDFs. Acrobat 8 Reader is a free download: http://www.adobe.com/products/acrobat/readstep2.html

Once you have Acrobat Reader 8 on your PC and open the proof, you will see the Commenting Toolbar (if it does not appear automatically go to Tools>Commenting>Commenting Toolbar). The Commenting Toolbar looks like this:

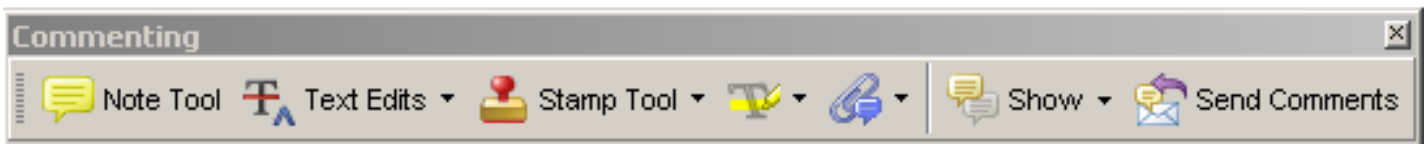

If you experience problems annotating files in Adobe Acrobat Reader 9 then you may need to change a preference setting in order to edit.

In the "Documents" category under "Edit - Preferences", please select the category 'Documents' and change the setting "PDF/A mode:" to "Never".

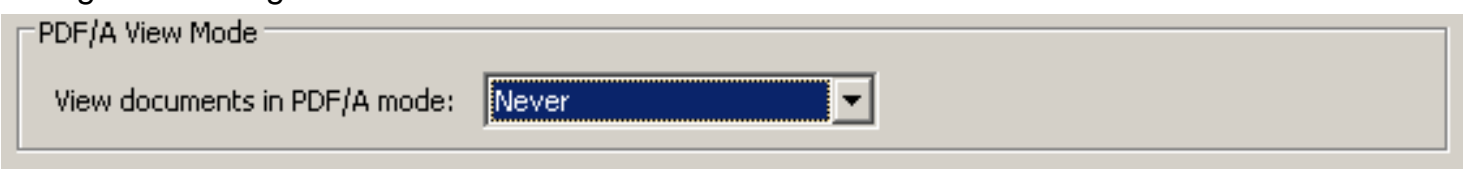

\section{Note Tool - For making notes at specific points in the text}

Marks a point on the paper where a note or question needs to be addressed.

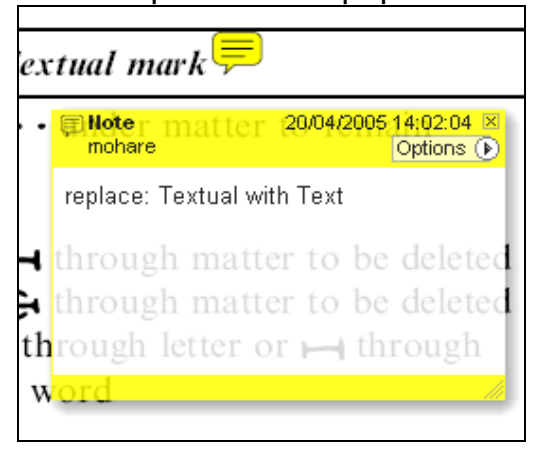

\section{How to use it:}

1. Right click into area of either inserted text or relevance to note

2. Select Add Note and a yellow speech bubble symbol and text box will appear

3. Type comment into the text box

4. Click the $X$ in the top right hand corner of the note box to close.

\section{Replacement text tool - For deleting one word/section of text and replacing it}

Strikes red line through text and opens up a replacement text box.

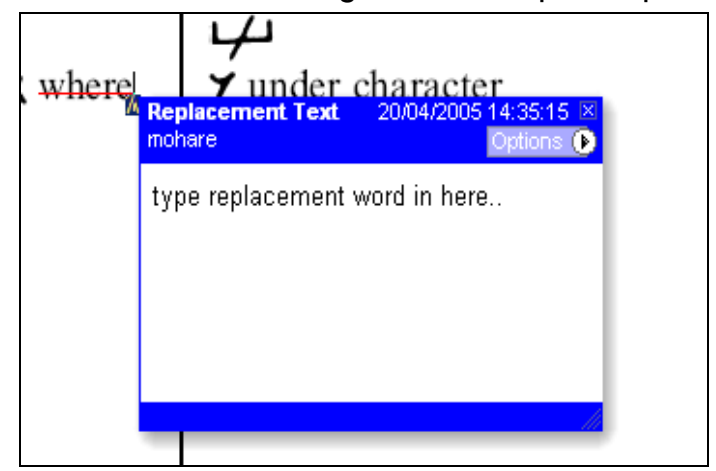
How to use it:
1. Select cursor from toolbar
2. Highlight word or sentence
3. Right click
4. Select Replace Text (Comment) option
5. Type replacement text in blue box
6. Click outside of the blue box to close

\section{Cross out text tool - For deleting text when there is nothing to replace selection}

Strikes through text in a red line.

\begin{tabular}{|l|}
\hline substitute part of one or \\
more word(s) \\
Change to italies \\
Change to capitals \\
Change to small capitals \\
\hline
\end{tabular}
How to use it:
1. Select cursor from toolbar
2. Highlight word or sentence
3. Right click
4. Select Cross Out Text 


\section{WILEY-BLACKWELL}

Approved tool - For approving a proof and that no corrections at all are required.

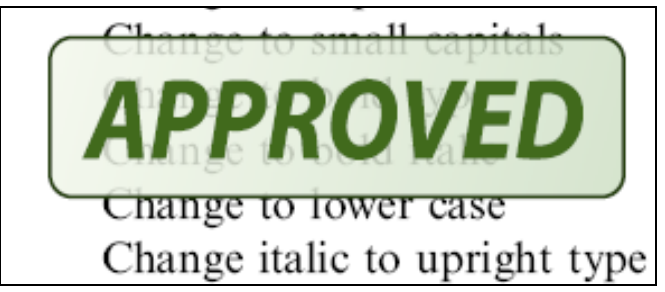

\section{How to use it:}

1. Click on the Stamp Tool in the toolbar

2. Select the Approved rubber stamp from the 'standard business' selection

3. Click on the text where you want to rubber stamp to appear (usually first page)

Highlight tool - For highlighting selection that should be changed to bold or italic. Highlights text in yellow and opens up a text box.

\begin{tabular}{|c|c|}
\hline & \\
\hline puble quotation & (As above) \\
\hline phen $\begin{array}{c}\text { Highlight } \\
\text { mohare }\end{array}$ & $\begin{array}{l}\text { 20:04:2005 14:45:47 } x \\
\text { Options (i) }\end{array}$ \\
\hline N par & \\
\hline parą & \\
\hline $\mathrm{se}$ & \\
\hline$p$ & \\
\hline ace b & \\
\hline
\end{tabular}

\section{How to use it:}

1. Select Highlighter Tool from the commenting toolbar

2. Highlight the desired text

3. Add a note detailing the required change

Attach File Tool - For inserting large amounts of text or replacement figures as a files. Inserts symbol and speech bubble where a file has been inserted.

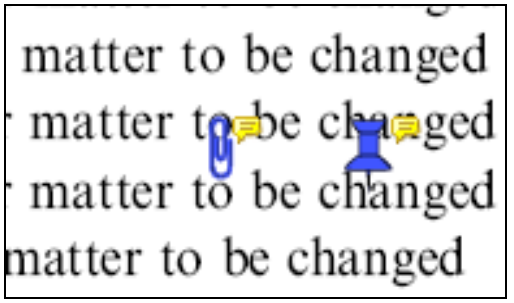

How to use it:

1. Click on paperclip icon in the commenting toolbar

2. Click where you want to insert the attachment

3. Select the saved file from your PC/network

4. Select appearance of icon (paperclip, graph, attachment or tag) and close

\section{Pencil tool - For circling parts of figures or making freeform marks}

Creates freeform shapes with a pencil tool. Particularly with graphics within the proof it may be useful to use the Drawing Markups toolbar. These tools allow you to draw circles, lines and comment on these marks.

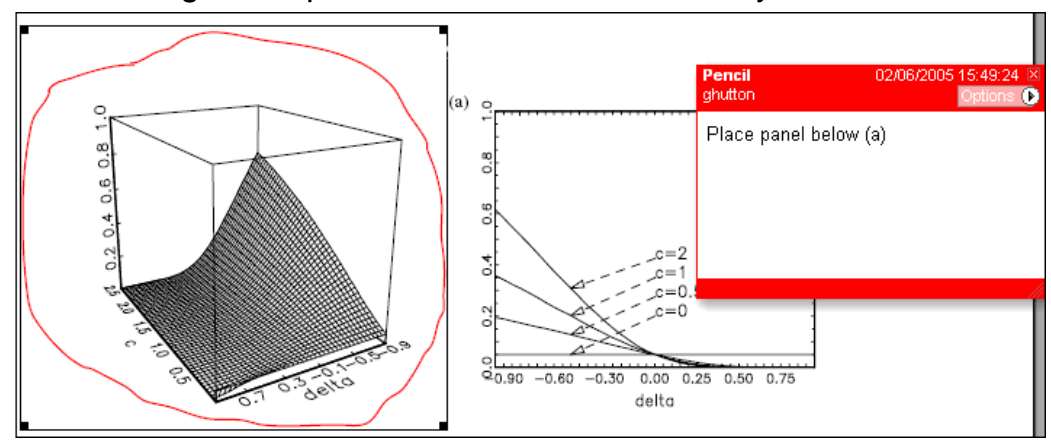

How to use it:

1. Select Tools $>$ Drawing Markups $>$ Pencil Tool

2. Draw with the cursor

3. Multiple pieces of pencil annotation can be grouped together

4. Once finished, move the cursor over the shape until an arrowhead appears and right click

5. Select Open Pop-Up Note and type in a details of required change

6. Click the $X$ in the top right hand corner of the note box to close. 
Help

For further information on how to annotate proofs click on the Help button to activate a list of instructions:

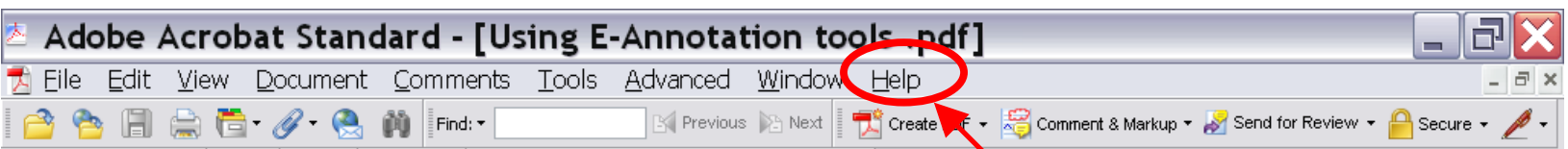

